\title{
Density-dependent effect of allelopathy on germination and seedling emergence in two Ipomoea species
}

\author{
Zoila Mercedes Aguilar-Franco ${ }^{1}$, Alejandro Flores-Palacios ${ }^{2} \mathbb{B}$, Alejandro Flores-Morales ${ }^{1} \mathbb{B}$, Irene Perea-Arango ${ }^{3}$ (D), \\ José de Jesús Arellano-García ${ }^{3}$ (i) and Susana Valencia-Díaz ${ }^{3^{*}}$ (B)
}

\begin{abstract}
Background: Density in inter and intraspecific plant-plant interactions affects the action modes of allelopathy (autotoxicity, negative and positive allelopathy). Some seeds exude compounds that inhibit the germination of others. Ipomoea murucoides and I. pauciflora are sympatric tree species that form patches at the local scale where one or the other dominates, possibly due to allelopathy in the seeds. The objective of this study was to determine the possible density-dependence of the allelopathic effect among seeds of these species through the measure of seed germination and seedling emergence.

Methods: In both species, allelopathy was measured as: a) germination in mixed sowing of both species at different proportions, b) germination in single-species trials at different densities after adding seed extracts of both species, and c) seedling emergence in seed mixtures of both species sown at different proportions beneath canopies of the two Ipomoea species.

Results: Seed germination of I. murucoides was increased by the presence of I. pauciflora and diminished at higher densities of its own seeds; however, seed germination of I. pauciflora was not affected by the presence of $I$. murucoides seeds. The addition of extracts (either from conspecifics or congeneric) diminished the germination of both species and at higher seed densities the germination was lower. Seedling emergence did not depend on the species under which the seeds were sown nor on the density of the seeds.

Conclusions: The germination experiments evidenced positive allelopathy and/or autotoxicity, while there was no evidence of allelopathic effects in seedling emergence. The allelopathic activity is reported in the seeds of these species for the first time.
\end{abstract}

Keywords: Autotoxicity, Chemical interference, Facilitation, Replacement series experiment, Resource competition, Tropical dry forest

\section{Background}

Allelopathy has traditionally been considered as a chemical interference, which takes place when one plant reduces the growth of another through chemical mechanisms [1-4]. However, according to other definitions, allelopathy includes also beneficial effects on other plants. Rice [5] defined allelopathy as any direct or

\footnotetext{
* Correspondence: susana.valencia@uaem.mx

${ }^{3}$ Centro de Investigación en Biotecnología (CEIB), Universidad Autónoma del Estado de Morelos, Av. Universidad 1001. Col. Chamilpa, C. P. 62209 Cuernavaca, Morelos, Mexico

Full list of author information is available at the end of the article
}

indirect effect, positive or negative, on the development of an acceptor plant, or microorganisms, as a consequence of the release of secondary metabolites to the environment by a donor organism. In seeds, it has been documented that exudates generated during germination can inhibit the seed germination of other species [6-10]. For example, some seeds possess non-protein amino acids that function as inhibitors of basic metabolism [11, 12], interfering with auxin transport, protein synthesis, polypeptide elongation [13] and root development [14]. However, seeds may also exude molecules that act like phytohormones promoting plant growth (e.g. lepidimoide from

(c) The Author(s). 2019 Open Access This article is distributed under the terms of the Creative Commons Attribution 4.0 International License (http://creativecommons.org/licenses/by/4.0/), which permits unrestricted use, distribution, and 
Lepidium sativum) $[15,16]$. Lepidimoide has been found to increase the hypocotyl length of Amaranthus caudatus [15], the light-induced chlorophyll content in cotyledons of Helianthus annus [17], and the number of leaves and seed production of Arabidopsis thaliana [18]. On the other hand, a negative form of intraspecific allelopathy, also called autotoxicity or autoallelopathy, occurs when plants exert harmful effects on the growth of its conspecifics [19]. For example, it has been found that diterpenes from leaves of Cistus ladanifer inhibited the seed germination, seedling size and seedling establishment at intraspecific level [20].

Allelopathic effects could be related to the density of interacting plants. Especially when allelopathy exerts a negative effect on acceptor plants [21-24]. It has been found that at higher seed density of Carduus nutans the germination rate of Lolium perenne and Trifolium subterraneum diminished [7]. Similar results have been found in mixture crops when Sesamum indicum diminished the root length of Gossypium hirsutum [25], or when increasing plant number of Triticum aestivum diminished the biomass of Avena fatua [26]. Thus, different densities of the interacting plants may lead to different allelochemical concentrations, and therefore density should be taken into account when allelopathy experiments are performed [27]. In a scenario in which two species interact and considering a fixed concentration of allelochemicals in the environment, a low density of acceptor plants will be exposed to a greater concentration of allelochemicals per plant and this will affect more negatively their performance (e.g. growth, seed germination, seedling emergence). Contrary, at a high density of acceptors, the concentration of allelopathic compounds reaching a plant will be lower.

Some Ipomoea (Convolvulaceae) species have been reported to have allelopathic activity (e. g. Ipomoea tricolor Cav [28]). Bark extracts from Ipomoea murucoides Roem. et Schult. and I. pauciflora M. Martens \& Galeotti were found to negatively affect the seed germination of epiphytic bromeliads [29]. Additionally, it has been documented that seeds of I. murucoides contain fatty acids and glycosidic resins [30], both of which have allelopathic properties [28]. Ipomoea pauciflora and I. murucoides are sympatric species present at a high density in the tropical deciduous forest of central Mexico [31]. It is common to find groups of both species where one of them dominates. This pattern could result from one species exerting a form of allelopathy (negative or positive) on the seed germination and/or seedling emergence of the other species. Alternatively, this pattern could reflect autotoxicity, i.e., germination and emergence are reduced by high seed and/or seedling density of conspecifics. In this study, three experiments were conducted to test if seeds of Ipomoea pauciflora and I. murucoides affect the germination and emergence of conspecifics and congenerics through mechanisms of allelopathy. The first experiment evaluated if variable proportions of seeds of both species inhibit (autotoxicity, negative allelopathy) or promote (positive allelopathy) the seed germination of the interacting species. The second experiment assessed the allelopathic activity (positive or negative) of aqueous seed extracts of each species on conspecifics and congenerics seed germination at different seed densities. Finally, an outdoor experiment evaluated the effect of Ipomoea canopy identity on the seedling emergence of $I$. murucoides and I. pauciflora sown at different proportions. It is expected that if the germination and/or seedling emergence of Ipomoea murucoides and I. pauciflora are affected by density-dependent negative allelopathy exerted by seeds of their congenerics, these two processes should be reduced when seeds of one species are sown with high densities of the other species; conversely, if both processes are affected by density-dependent positive allelopathy, germination and seedling emergence should be promoted when seeds of one species are exposed to high seed densities of the other species. On the other hand, decreased germination and/or seedling emergence of I. murucoides and I. pauciflora at high densities of their conspecifics should suggest autoxicity, because concentration of toxic substances increases along with plant density.

\section{Methods}

\section{Study site and species}

The seed collection and field experiment were conducted on the hill "Cerro de la Cruz", located in the municipality of Tepoztlán $\left(18^{\circ} 57^{\prime} 22.2^{\prime \prime} \mathrm{W}, 99^{\circ} 06^{\prime} 50.2^{\prime \prime}\right.$ N, 1495 m a.s.l.), Morelos State, México. Mean summer (plant growing season) precipitation at this area is $511 \pm$ $21.82 \mathrm{~mm}$ and mean summer temperature is $20.65 \pm$ $0.65^{\circ} \mathrm{C}$ (https://smn.conagua.gob.mx/es/informacionclimatologica-por-estado?estado=mor). The hill has c. $13 \mathrm{~km}^{2}$ and forms part of the "Chichinautzin" Biological Corridor, considered a protected area for the flora and fauna (http://www.dof.gob.mx/nota_detalle. php? codigo $=4793772 \&$ fecha $=30 / 11 / 1988)$. The vegeta tion type is tropical dry forest, which is characterized by an open canopy and trees of low stature [32]. The study area contains at least 42 tree species, six of them with a relative dominance (RD) higher than 5\%: Conzattia multiflora (B.L. Rob.) Standl. (Fabaceae, RD =14.9\%), Bursera fagaroides (Kunth) Engl. and Bursera glabrifolia (Kunth) Engl. (Burseraceae, both with $\mathrm{RD}=14.7 \%$ ), Sapium macrocarpum Müll. Arg. (Euphorbiaceae, $\mathrm{RD}=12.5 \%$ ), Ipomoea murucoides $(\mathrm{RD}=5.6 \%)$ and I. pauciflora $(\mathrm{RD}=7.1 \%)$ [31].

Ipomoea murucoides is a tree $3-8 \mathrm{~m}$ tall, up to $40 \mathrm{~cm}$ diameter at breast height. Their leaves are oblong-elliptical, the inflorescence has one or two white flowers, and the fruit is an ovoid capsule with four seeds [33]. Ipomoea pauciflora is a tree up to $8 \mathrm{~m}$ tall, with ovate leaves 
5-15 cm length, inflorescences with one to five white flowers, and capsules with often four seeds, rarely five [33]. These species are native of tropical America, characteristic of both perturbed and pristine tropical dry forest. In both species the flowering season occurs from October to March, fruit set begins in January and finishes in April [33], seeds are dispersed from March to April and seed germination occurs during summer months (June-September).

\section{Seed collection}

In March and April 2015, and prior to fruit dehiscence, approximately 150 capsules per tree were collected from twelve trees of I. murucoides and ten trees of I. pauciflora. These capsules were stored in paper bags until dehiscence. The seeds were separated from the pericarp and the dispersion appendices removed in order to prevent moisture retention and proliferation of fungi. Parasitized (presence of holes) and/or non-vigorous seeds were discarded. Seeds were then mixed and stored until the beginning of the experiments (May-July 2015).

Given that seeds of Ipomoea murucoides present physical dormancy [34], and seeds of I. pauciflora apparently present a similar seed coat hardness, prior to each experiment performed in this research, the seeds of both species were scarified with sandpaper (Fandeli A-99280). Appropriate scarification was achieved by taking one seed at a time and scraping it laterally against the sandpaper. Scarification finished when the seed coat was reduced, and the endosperm was intact but exposed. Once scarified, the seeds were disinfected with $0.25 \%$ sodium hypochlorite for $1 \mathrm{~min}$. and rinsed three times with distilled water.

Effect of different seed proportions of $I$. murucoides and $I$. pauciflora on germination (experiment 1)

A replacement series experiment [35] was conducted to establish whether seed germination in I. murucoides and I. pauciflora is inhibited or promoted when seeds of one species replace gradually seeds of the other species. Sixteen seeds were randomly chosen and sown, using filter paper as a substrate, in each of ten Petri dishes $(90 \mathrm{~mm}$ diameter $\times 15 \mathrm{~mm}$ height, i.e. the replicates) per treatment. Treatments of the replacement series experiment consisted of different proportions of I. murucoides and $I$. pauciflora seeds: 16:0, 14:2, 12:4, 10:6, 8:8, 6:10, 4:12, 2: 14, 0:16. In each Petri dish, seeds were arranged systematically in four lines with four seeds each $(4 \times 4)$. When treatments involved seed of both species, these were alternated. The Petri dishes were watered with $10 \mathrm{~mL}$ of distilled water and then were sealed with Parafilm (Pechiney-Plastic packaging, model PM-996, USA) and Clingfilm (Kirkland Signature, model 26,761, USA) in order to avoid moisture loss. The sealed dishes were then placed in a growth chamber from May 18 to June
7, 2015 (Scorpion Scientific A 50624, Mexico), at a temperature of $25^{\circ} \mathrm{C}$ and a photoperiod of $12 \mathrm{~h}$ light and $12 \mathrm{~h}$ darkness. To ensure a correct seed identification when data were recorded, the $I$. murucoides seeds were marked with a yellow color drop of textile paint (Confetti, Mexico; No. 112) while I. pauciflora was similarly marked with blue color (No. 125). Preliminary germination experiments using the same sowing protocol described above, showed that the paint had no significant effect neither on the germination of $I$. murucoides $(\bar{x} \pm \mathrm{SD}$ without and with paint, respectively: $33.33 \pm 30.55 \%$ and $33.33 \pm 11.54 \%$; Mann- Whitney test, $U=4.0, P=0.82$ ) nor on the germination in I. pauciflora $(\bar{x} \pm \mathrm{SD}$ without and with paint, respectively: $46.66 \pm 11.54 \%$ and $46.66 \pm 11.54 \%$ ) (MannWhitney test, $U=4.5 ; P=1.00$ ). Seed germination was recorded daily for 14 days; after this period the experiment was ended. Germination was considered successful when the radicle emergence was visible. Germination was computed for each replicate, per species and treatment.

\section{Effect of seed aqueous extracts and seed density on seed germination of conspecifics and congenerics (experiment 2)} This experiment was conducted to determine the effect of seed extracts of each species on the seed germination of their congeneric counterparts and themselves (autoallelopathy). Ipomoea murucoides and I. pauciflora seeds were sown at different densities (see below) and watered with seed extracts of the same and the other species. Liquid extracts of both Ipomoea species were obtained following Maiti et al. [36]. For this, $300 \mathrm{~g}$ of seeds of each species were dried in a forced fan oven (FD 115$\mathrm{UL}$, Binder) for $24 \mathrm{~h}$ at $28^{\circ} \mathrm{C}$. Due to their physical dormancy [34] and the hard seed coats (which impede the flux of allelochemicals) [11], the seeds of Ipomoea were partially crushed in an electrical coffee mill (Krups model GX410011V). The crushed seeds of both species were then macerated at ambient temperature in $500 \mathrm{~mL}$ of distilled water. After $24 \mathrm{~h}$, these samples were vacuum filtered three times with a Buchner funnel. The liquid seed extracts of both species were then lyophilized (lyophilization equipment LABCONCO, Frezone 1) and used in the germination experiments. Seeds of $I$. murucoides and I. pauciflora were scarified, disinfected and then sown separately at three different densities: 8,12 and 16 seeds per Petri dish $(90 \mathrm{~mm}$ diameter $\times 15 \mathrm{~mm}$ height), using filter paper as a substrate. Seeds of both species of Ipomoea and at each density were watered with seed extracts of conspecifics and the congeneric. Five Petri dishes (i.e. the replicates) were used per species, density, and watering seed extract. One $\mathrm{mL}$ of extract $(1 \mathrm{~g} / \mathrm{mL})$ per seed was added to each Petri dish, (e.g. $8 \mathrm{~mL}$ for Petri dishes with 8 seeds). In order to differentiate the effect of the extract with the volume of solution added to the Petri dishes, controls with five 
replicates each were established for each species and seed density, in which 8,12 and $16 \mathrm{~mL}$ of distilled water was added. All Petri dishes were randomly placed in a growth chamber under similar conditions as described for experiment 1 . Seed germination was counted when the radicle emergence was visible.

\section{Effect of seed proportion and canopy identity on seedling emergence (experiment 3)}

In order to determine if allelopathy and/or autoallelopathy affect seedling emergence under natural conditions, an in situ outdoor experiment was established in late May 2015. Three contiguous sites were chosen in the study area, one visually dominated by $I$. murucoides (site 1), another dominated by I. pauciflora (site 2), and a third site (control) where both Ipomoea species and other tree species were absent, however scarce herbs and grasses were present. In sites 1 and 2, five trees of $I$. murucoides and I. pauciflora, respectively, were selected and labeled with flagging tape. Around each tree (i.e. replicate), and at a distance of $1.5 \mathrm{~m}$ from the trunk, five boxes of reinforced, galvanized steel mosquito screen mesh $(12 \mathrm{~cm}$ in length $\times 7 \mathrm{~cm}$ in with $\times 8 \mathrm{~cm}$ in height) were buried in the soil. An imaginary grid was traced in each box, dividing it into eighths, and one seed was assigned at random to each eighth. These seeds were sown at a depth of $<1 \mathrm{~cm}$. Seeds of $I$. murucoides and $I$. pauciflora were sown at different proportions (i.e. the treatments) in each of the five boxes. Five proportions were considered: 8:0, 6:2, 4:4, 2:6 and 0:8. In the control site, six points were established, each with the same five seed density treatments of the two Ipomoea species. The seeds and seedlings of both species are morphologically similar and hence may be difficult to distinguish each other; thus, in order to ensure accurate identification of the seedlings, the I. pauciflora seeds were identified by placing a colored thumbtack next to each. Once this experiment was established, the boxes were reviewed weekly from May 2015 to January 2016 (mean temperature and precipitation for this period: $22.43 \pm 1.32^{\circ} \mathrm{C}$ and $139 \pm$ $116.11 \mathrm{~mm}$; https://smn.conagua.gob.mx/), and the number of emerged seedlings per species and treatment was recorded at each site.

\section{Statistical analyses}

Data of all the experiments were analyzed using generalized linear mixed models (GLMM) [37, 38]. For experiments 1 and 2, the Petri dish was considered the random factor; for experiment 3 the random factor was the tree under which the seeds were sown. For experiment 1 , analyses were performed separately for each species; here the fixed factor was the seed proportion, while the response variable was the seed germination of each Ipomoea species. In experiment 2 , the proportion of germinated seeds was the response variable, while the fixed factors were the seed density (8, 12, 16 seeds), the source of aqueous extract (I. murucoides, I. pauciflora or distilled water) and the species (I. murucoides or I. pauciflora). In experiment 3 , the response variable was the proportion of seedling emergence, while the fixed factors were the condition under which the seeds were sown (I. murucoides canopy, I. pauciflora canopy, or control -i.e., no canopy-), the seed proportion and the species (I. murucoides, I. pauciflora). All statistical analyses were carried out using $\mathrm{R}$ version 3.4.3. (R Core Team 2017 [39]) with library lme4 using a binomial link function [38]. In case of statistical differences, post hoc Tukey test were performed with multicomp package [40].

\section{Results}

\section{Effect of variation in seed proportion on seed} germination (experiment 1)

Without considering the seed proportion, the total percentage of germination for $I$. murucoides was of $34.81 \pm 0.14 \%$, while for I. pauciflora was $28.78 \pm 11.54 \%$. Ipomoea murucoides reached lower germination rate in the absence of $I$. pauciflora $\left(X_{1}^{2}=7.2, P<0.0001\right.$; Fig. $\left.1 \mathrm{a}\right)$, while seed germination of $I$. pauciflora was not affected by the increment of seed proportion of I. murucoides $\left(\chi^{2}{ }_{1}=3.5, P=0.06\right.$; Fig. 1b).

\section{Effect of seed aqueous extracts and seed density on seed} germination of conspecifics and congenerics (experiment 2) Germination of I. murucoides and I. pauciflora was statistically similar (both with $78 \pm 24 \%$, Table 1 ). However, the source of aqueous extracts provoked differences in seed germination of both species (Table 1). Germination of $I$. murucoides was lower ( $46 \pm 17 \%$, across densities) when watered with extracts of I. pauciflora than when were watered with its own extract $(75 \pm 21 \%$ across densities, Fig. 2a, b). By contrast, germination of I. pauciflora was similar under the two types of extracts (Fig. 2f, g). Mean germination in controls was always above $80 \%$ (8 $\mathrm{mL}, 80 \pm 28 \%$; $12 \mathrm{~mL}, 94 \pm 9 \%$; $16 \mathrm{~mL}, 93 \pm 9 \%$, Fig. 2c, d, $e, h, i, j)$. When seeds where watered with aqueous seed extracts, the lowest germination in both species was observed in the highest density (16 seeds) (Table 1 , Fig. 2a, b, f, g). However, no consistent pattern of germination in relation to seed density was observed in the three controls; for example, with $8 \mathrm{~mL}$ of distilled water, germination of $I$. murucoides increased with seed density but germination of I. pauciflora did not. Also, with 12 $\mathrm{mL}$ I. pauciflora had the lowest germination at intermediate density, while with $16 \mathrm{~mL}$ the germination of both species diminished with the increment of seed density (Fig. 2c, d, e, h, i, j). 

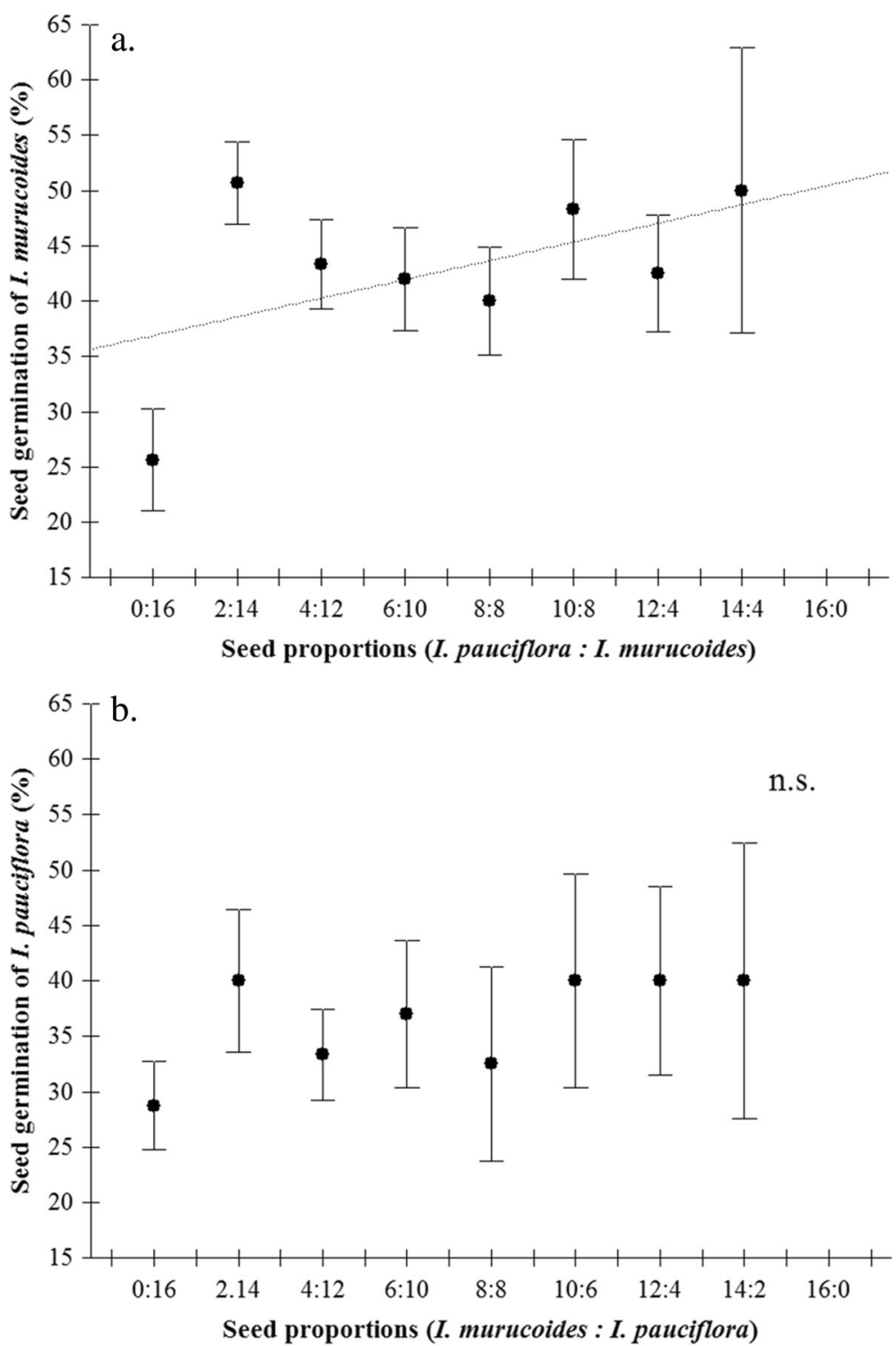

Fig. 1 Percentage of germination in vitro (mean \pm SE) of seeds of a Ipomoea murucoides in response to seed proportions of I. pauciflora: I. murucoides and of $\mathbf{b}$ I. pauciflora in response to seed proportions of I. murucoides: I. pauciflora. n.s. = not significant

Effect of seed proportion and canopy identity on seedling emergence (experiment 3)

Seedling emergence was statistically similar (Table 2) under I. murucoides $(15.44 \pm 11.79 \%)$, I. pauciflora (12.81 $\pm 7.45 \%)$ and the control $(15.83 \pm 10.88 \%)$. There was no effect of the seed proportion of $I$. murucoides and I. pauciflora on the seedling emergence of these species (Table 2). However, seedling emergence was statistically lower in $I$. murucoides $(9.7 \pm 8.1 \%)$ than in I. pauciflora $(19.7 \pm 273$ $10.8 \%$, Tables 2 and 3).

\section{Discussion}

Traditionally, research in allelopathy has focused in the chemical negative interference that a plant species exerts on another. However; in plant-plant interactions allelopathy could play a positive role too, when a plant facilitates the growth of others [5]. Besides, intraspecific allelopathy also occurs when plants of the same species diminish their own growth (autotoxicity) [19]. Results of this research demonstrate that both negative and positive allelopathy in seeds of $I$. murucoides and $I$. pauciflora depend on seed density.

Assuming a constant supply of allelochemicals, the established theory predicts that their effect will be greater on receptor plants at low density, since the quantity of allelochemicals is shared among a smaller number of individuals [22]. When the density of seeds of the receptor species Carduus acanthoides increased relative to the 
Table 1 Degrees of freedom (D. F.), X2 and P-value of generalized a linear mixed-effects model testing the effects of seed density, species (Ipomoea murucoides, I. pauciflora), and type of aqueous extract (seed extract of I. murucoides, seed extract of I. pauciflora, and water) on seed germination of $I$. murucoides and I. pauciflora

\begin{tabular}{llll}
\hline Source of variation & D. F. & $X^{2}$ & $P$ \\
\hline Aqueous extract & 4 & 286.8 & $2.2 e^{-16}$ \\
Seed species & 1 & 1.04 & 0.3076 \\
Seed density & 1 & 14.13 & 0.00017 \\
Aqueous extract $\times$ seed species & 4 & 35.35 & $3.93 e^{-07}$ \\
Aqueous extract $\times$ seed density & 4 & 71.71 & $9.86 e^{-15}$ \\
Seed species $\times$ seed density & 1 & 0.80 & 0.3706 \\
Aqueous extract $\times$ seed species $\times$ seed density & 4 & 9.81 & 0.043 \\
\hline
\end{tabular}

donor Lotus tenuis, the receptor exhibited fewer negative effects on its germination [41]. On the other hand, when the density of the donor species Ligularia virgaurea increased, the seed germination of the receptor species Festuca sinensis and Agrostis giganteum decreased [42]. The results found here differ from these studies since by increasing the proportion of seeds of I. pauciflora the percentage of seed germination of $I$. murucoides increased. This can be explained by two non-exclusive mechanisms. The first is positive allelopathy [5, 43]; the exudates of the seeds that are present in greater proportion (I. pauciflora,
Fig. 1a) could facilitate seed germination in the species present at lower density (I. murucoides). In line with these results, specific molecules (i.e. strigolactones) have been found to promote seed germination in parasitic plants (i.e. Orobanche spp., Striga spp.) [44]. Autotoxicity is the second mechanism that may explain the increment in seed germination of $I$. murucoides when seed density of I. pauciflora increased. Autotoxicity could help to regulate the population size of species with high density through autotoxic allelochemicals. Autotoxins can delay seed germination until seeds are dispersed at a given distance from the progenitor plant, thus preventing parental and sibling competition [19]. It is possible that I. murucoides seeds exude autotoxic allelochemicals during the process of germination; in fact, the seeds of this species contain glycosidic resins which were found to inhibit the seed germination of conspecifics and heterospecifics $[45,46]$. Glycosidic resins are characteristic in the Convolvulaceae family [45]; for example, Tricolorin-A obtained from I. tricolor, inhibited the seed germination of Amaranthus hypochondriacus [46]. As found here, the probability of autotoxicity may increase at higher densities of the plantreleasing toxins [47].

Contrary to the effect of I. pauciflora on I. murucoides, variations in the seed proportion of $I$. murucoides did not exert any allelopathic activity in seed germination of I. pauciflora Why these two similar species (trees,

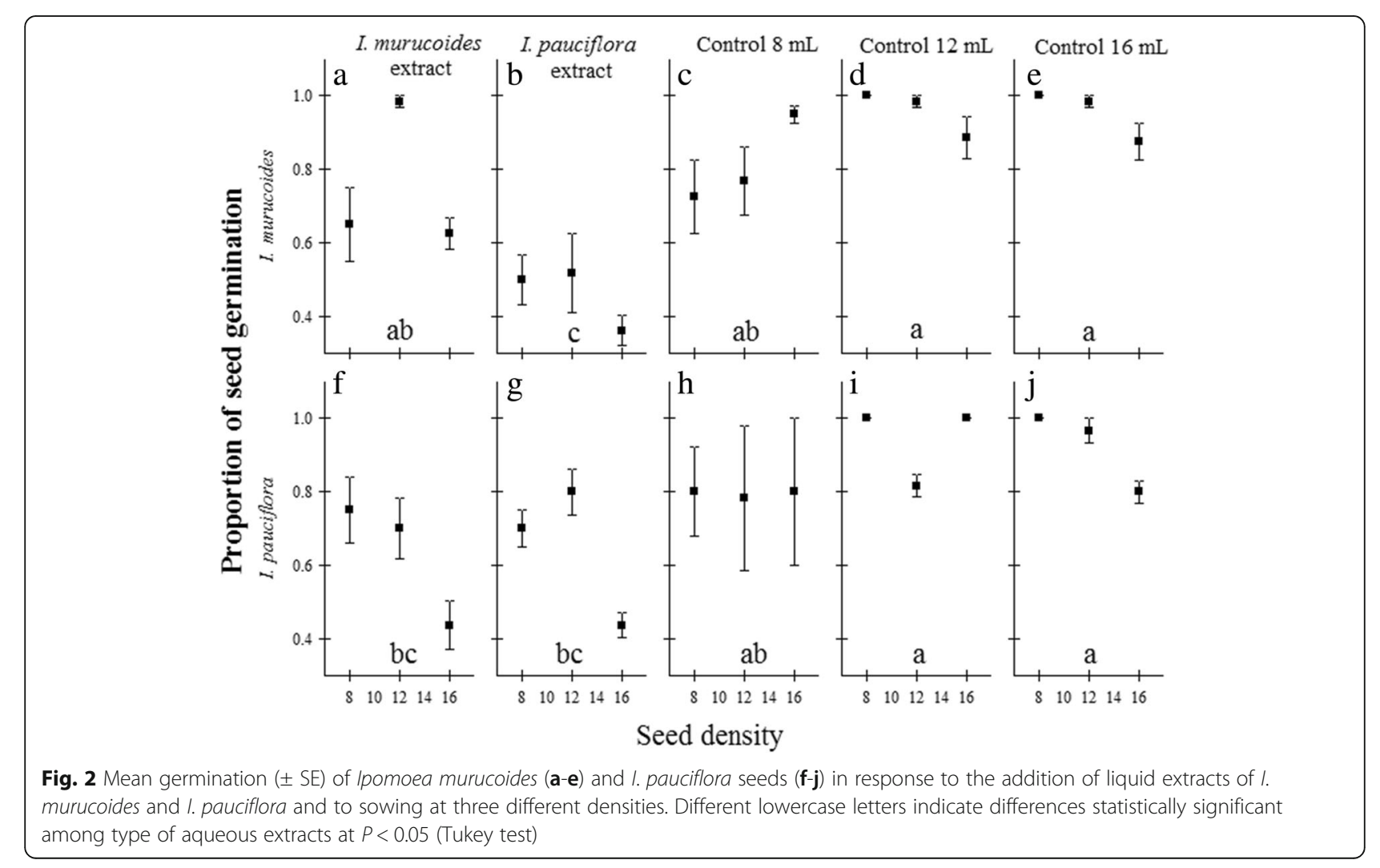


Table 2 Degrees of freedom (D. F.), X2 and $P$-value of the generalized linear mixed-effects model analysis testing the effects of seed species (Ipomoea murucoides, I. pauciflora), Type of canopy (I. murucoides, I. pauciflora, control area) and seed proportion of I. murucoides: I.pauciflora (8:0, 6:2, 4:4, 2:6 and 0:8) on seedling emergence of I. murucoides and I. pauciflora

\begin{tabular}{llll}
\hline Source of variation & D.F. & $X^{2}$ & $P$ \\
\hline Seed species & 1 & 9.286 & 0.0023 \\
Type of canopy & 2 & 1.0029 & 0.6057 \\
Seed density & 1 & 0.3334 & 0.5637 \\
Seed species $\times$ Type Canopy & 2 & 1.2769 & 0.5281 \\
Seed species $\times$ Seed density & 1 & 0.3685 & 0.5438 \\
Type of Canopy $\times$ Seed density & 2 & 5.8182 & 0.0545 \\
Seed species $\times$ Type of Canopy $\times$ Seed density & 2 & 1.8806 & 0.3905 \\
\hline
\end{tabular}

phylogenetically related, sympatric and allelopathic) exerted different effects in the seed germination of the other species? Previously, it has been shown that both species maintain chemical differences in their bark [29]. Bark of $I$. murucoides had three non-shared compounds with I. pauciflora (.psi ... psi.-carotene.7,7,8,8,11,11,12,12, 15,15-decahydro, n-hexadecanoic acid and Octadec-9Zenol) [29]. Early reports have shown that n-hexadecanoic acid diminished seed germination of other species [29, 48]. Although chemical profiles of seeds of $I$. murucoides and $I$. pauciflora are unknown, n-hexadecanoic could be present in seeds of I. murucoides causing autoinhibition. The autotoxic effect seems to depend on the I. murucoides seed density. Possibly, at a higher seed density of this species, the concentration of $\mathrm{n}$-hexadecanoic acid increases, as well as its inhibitory effect.

The seed extract watering experiment (experiment 2) corroborated that both species are allelopathic [29], since germination was reduced relative to the control. Moreover, at higher seed density the germination of $I$. murucoides and I. pauciflora diminished. It is unlikely that water depletion has reduced the germination when seeds were at high densities, because the water volume also increased with seed density. It is possible that germinant seedlings compete for resources like space or light. The results from experiment 2 differed from those

Table 3 Percentage of seedling emergence $(\bar{X} \pm$ SD) of Ipomoea murucoides and I. pauciflora sown below trees of I. murucoides and I. pauciflora and in the control area

\begin{tabular}{lll}
\hline Seed species & Tree species & Seedling emergence (\%) \\
\hline I. murucoides & I. murucoides & $10.76 \pm 9.23$ \\
& I. pauciflora & $7.5 \pm 8.66$ \\
I. pauciflora & Control & $10.83 \pm 8.33$ \\
& I. murucoides & $20.13 \pm 14.36$ \\
& I. pauciflora & $18.12 \pm 6.25$ \\
& Control & $20.83 \pm 13.43$ \\
\hline
\end{tabular}

of experiment 1, as I. murucoides did not increase its germination when watered with $I$. pauciflora exudates (supportive of positive allelopathy, see above), neither when it was sown at low densities (supportive of autotoxicity). The inconsistencies between the results obtained in both germination experiments could be due to the methodology performed to study allelopathy [49]. It is possible that allelochemicals with autotoxic or positive allelopathic (see above) properties were exuded during seed germination. If so, allelopathic or autoxic effects had occurred in the first germination experiment only, when seeds of the two Ipomoea species were combined in the seed trials. It is also possible that, as stated by Duke [20], the water employed to make seed extractions may have oxidized enzymes (i.e., polyphenol oxidase and peroxidase) and these in turn may have modified compounds exuded naturally during germination and thus altered their biological activity.

The study of seeds as allelopathic units during their germination in the seed to seed interaction is a little studied phenomenon $[7,10,11,41]$. This lack of research is caused by several methodological limitations; for example, seeds are usually of small size (limiting the amount of available tissue), some have some kind of dormancy [50] and their metabolism rapidly change during the germination process [50]. It has been found that allelochemicals may be localized in different seed tissues like seed coat or cotyledons [11], in consequence the aqueous extracts obtained from Ipomoea fragmented seeds may contain chemical compounds from all seed tissues, and hence the results shown by this study (experiment 2) should be taken with caution. This study demonstrated the density-dependent allelopathic activity in seeds of I. murucoides and I. pauciflora. Subsequent studies should explore the autotoxic activity of seed exudates during germination, rather than liquid extracts.

\section{Effect of seed density and Ipomoea identity on seedling emergence of Ipomoea murucoides and I. pauciflora}

The Ipomoea identity and seed proportion did not affect the seedling emergence of none Ipomoea species under field conditions. Water scarcity or drought causes 35\% of seedling mortality at global scale [51], therefore this stressful factor could cause seedling death and the interruption of germination in the Ipomoea species thus explaining the lack of effects of canopy type and seed density in experiment 3 . Plants of tropical dry forest germinate, grow and sprout in summer when maximum precipitation occurs; although this experiment was carried out in summer, rainy did not occur daily, then periods of watering and drying could have caused failure in seed germination and seedling emergence of Ipomoea species. Biotic factors could also affect the seedling emergence of both species of Ipomoea, such as with 
allelochemicals released by leaf litter decomposition [52-54]. On the other hand, herbivory is considered the main factor that causes seedling mortality $(38 \%)[51,55]$. It is possible that in the field experiment ants diminished the seedlings of the Ipomoea species [56]. Finally, seedling emergence may have been underestimated. Emergence was registered when the seedlings protruded from the soil, therefore seeds that may have germinated but not emerged were not considered. Additionally, the measurements of emergence could have not been sufficiently frequent, hence missing those seedlings that emerged but lived shortly.

\section{Conclusions}

Three experiments were conducted to determinate the effect of seed density on the interplay of action modes of allelopathy. First, through a replacement series experiment, it was demonstrated that seed proportion and seed germination of I. murucoides were inversely proportional, which could be evidence of positive allelopathy and/or autotoxicity. The second experiment brought evidence of negative allelopathy when seed germination of $I$. murucoides and $I$. pauciflora diminished in response to watering with aqueous extracts and with the increment of seed density. Finally, there were no evidence of any kind of allelopathy in the outdoor experiment when considering seedling emergence as the response variable. These results demonstrated that a) seeds of I. murucoides and I. pauciflora had allelopathic activity and b) allelopathy had a density-dependent effect and different action modes (negative, positive or autotoxicity) could be present within the same interacting species.

\section{Abbreviations}

$m$ a.s.l.: Meters above sea level; min.: Minute; RD: Relative dominance

\section{Acknowledgements}

We thank D. Avilés-Montes and K. MacMillan for their valuable comments and revision of the English text. We appreciate the comments and criticisms of three anonymous reviewers. Special thanks to F. Piper for the observations that contributed to improve substantially the manuscript. We also thank C. Gutiérrez for lending us the lyophilization equipment and L. Valladares y D. Ocampo for technical assistance. An early version of this manuscript was prepared as the Bachelors thesis of ZMAF.

\section{Authors' contributions}

Experimental design: AF-P, SV-D. Field experiments: ZMA-F, AF-M, AF-P and JdJA-G. Laboratory experiments: ZMA-F, IP-A, SV-D. Data analysis: AF-P, SV-D. Manuscript preparation: ZMA-F, AF-P, AF-M, IP-A, JdJA-G and SV-D. All authors read and approved the final version of the manuscript.

\section{Funding}

This study was funded by the Programa para el Desarrollo Profesional Docente (PRODEP, No. carta de liberación DSA/103.5/1516986, Folio asignado a profesor UAEMOR-PTC-375). ZMAF thanks the scholarship from PRODEP.

\section{Availability of data and materials}

The datasets used and/or analysed during the current study are available from the corresponding author on reasonable request.
Ethics approval and consent to participate

Not applicable

\section{Consent for publication}

Not applicable

\section{Competing interests}

The authors declare that they have no competing interests.

\section{Author details}

${ }^{1}$ Facultad de Ciencias Biológicas, Universidad Autónoma del Estado de Morelos, Av. Universidad 1001. Col. Chamilpa, C. P. 62209 Cuernavaca, Morelos, Mexico. ${ }^{2}$ Centro de Investigación en Biodiversidad y Conservación (CIßYC), Universidad Autónoma del Estado de Morelos, Av. Universidad 1001. Col. Chamilpa, C. P. 62209 Cuernavaca, Morelos, Mexico. ${ }^{3}$ Centro de Investigación en Biotecnología (CEIB), Universidad Autónoma del Estado de Morelos, Av. Universidad 1001. Col. Chamilpa, C. P. 62209 Cuernavaca, Morelos, Mexico.

Received: 9 December 2018 Accepted: 4 September 2019

Published online: 14 September 2019

\section{References}

1. Callaway RM, Walker LR. Competition and facilitation: a synthetic approach to interactions in plant communities. Ecology. 1997;78:1958-65.

2. Ridenour WR, Callaway RM. The relative importance of allelopathy in interference: the effects of an invasive weed on a native bunchgrass. Oecologia. 2001;126:444-50.

3. Klanderud $\mathrm{K}$, Totland $\mathrm{O}$. The relative importance of neighbours and abiotic environmental conditions for populations dynamic parameters of two alpine species. J Ecol. 2005:93:493-501.

4. Pedrol N, González L, Reigosa MJ. Allelopathy and abiotic stress (chapter 9). In: Allelopathy: a physiological process with ecological implications: Reigosa MJ, Pedro N, González L. 2006. Springer, Dordrecht.

5. Rice EL. Allelopathy. New York: Academic; 1984.

6. Panasiuk O, Bills DD, Leather GR. Allelopathic influence of Sorghum bicolor on weeds during germination and early development on seedlings. J Chem Ecol. 1986;12:1-11.

7. Wardle DA, Ahmed M, Nicholson KS. Allelopathic influence of nodding thistle (Carduus nutans L.) seeds on germination and radicle growth of pasture plants. N Z J Agric Res. 1991;34:185-91.

8. Balicevic R, Ravlic M, Ravlic I. Allelopathic effect of aromatic and medicinal plants on Tripleurospermum inodorum (L.) C.H. Schultz. Herbologia. 2015:15:41-53.

9. Ravlic M, Balicevic R, Nokolic M, Sarajlic A. Assesment of allelopathic potential of fennel, rue and sage on weed species hoary cress (Lepidium draba). Not Bot Horti Agrobo. 2015;44:48-52.

10. Guido A, Hoss D, Pilkar VD. Exploring seed to seed effects for understanding invasive species succes. Pers Ecol Conser. 2017;15:234-8.

11. Friedman J, Waller CR. Seeds allelopathic agents. J Chem Ecol. 1983;9:1107-17.

12. Selmar D. Biosynthesis of cyanogenic glycosides, glucosinolates and nonprotein amino acids. Ann Plant Rev. 2010;40:92-181.

13. Duke SO, Dayan FE. Modes of action of phytotoxins from plants (Chapter 23). In: Allelopathy: a physiological process with ecological implications: Reigosa MJ, Pedro N, González L. 2006. Springer, Dordrecht.

14. Bertin C, Weston LA, Huang T, Jander G, Owens T, Meinwald J, Shroeder FC. Grass root chemistry: meta-tyrosine, and herbicidal non protein amino acid. PNAS. 2007;104:16964-9.

15. Hasegawa K, Mizutani J, Kosemura S, Yamamura S. Isolation and identification of Lepidimoide a new allelopathic substance from mucilage of germinated cress seed. Plant Physiol. 1992;100:1059-61.

16. Yamada K, Kosemura S, Yamamura S, Hasegawa K. Exudation of an allelopathic substance lepidimoide from seeds during germination. Plant Growth Regul. 1997;22:189-92.

17. Yamada K, Matsumoto H, Ishizuka K, Miyamoto K, Kosemura S, Yamamura S, Hasegawa K. Lepidimoide promotes light-induced chrorophyll accumulation in cotyledons of sunflower seedlings. J Plant Growth Regul. 1998;17:215-9.

18. Goto N, Sando S, Sato Y, Hasegawa K. Effects of lepidiomoide on growth and development on Arabidopsis thaliana. J Weed Sci Tech. 1995:40:87-94.

19. Singh HP, Batish DR, Kohli RK. Autotoxicity: concepts, organisms and ecological significance. Crit Rev Plant Sci. 1999;18:757-72. 
20. Chaves LN, Ferrer de la Cruz I, Alías GJC. Autotoxicity of diterpenes present in leaves of Cistus ladanifer L. Plants. 2019;8:27. https://doi.org/10.3390/ plants8020027.

21. Chou CH, Lee YF. Allelopathic dominance of Miscanthus transmorrisonensis in an alpine grassland community in Taiwan. J Chem Ecol. 1991;17:2267-81.

22. Weidenhamer JD. Distinguishing allelopathy from resource competition: the role of density. In: Reigosa MJ, Pedrol N, González L, editors. Allelopathy a physiological process with ecological implications. Dordrecht: Springer; 2006. Chapter 4

23. Tielbörger $K$, Rüdiger $P$. Do seeds sense each other? Testing for densitydependent germination in desert perennial plants. Oikos. 2009;118:792-800.

24. Duke SO. Proving allelopathy in crop-weed interactions. Weed Sci. 2015;63:121-32

25. Shah AN, Iqbal J, Fahad S, Tanveer M, Yang G, Khan EA, Shahzad B, Yousaf M, Hassan W, Ullah A, Bukhari MA, Salah A, Saud S, Aalharby. Allelopathic influence if sesame and green gramm intercrops on cotton in a replacement series. Clean Soil Air Water. 2017;45:1-11.

26. $\mathrm{Li} \mathrm{YH}$, Xia Z-C, Kong $\mathrm{CH}$. Allelobiosis in the interference of allelopathic wheat with weeds. Pest Manag Sci. 2016;72:2146-53.

27. Inderjit, Weston LA. Are laboratory bioassays for allelopathy suitable for prediction of field response? J Chem Ecol. 2000;26:2111-8.

28. Pereda-Miranda R, Mata R. Tricolorin A, major phytogrowth inhibitor from Ipomoea tricolor. J Nat Prod. 1993;56:571-82.

29. Valencia-Díaz S, Flores-Palacios A, Rodríguez-López V, Ventura-Zapata E, Jiménez-Aparicio A. Effect of host-bark extracts on seed germination in Tillandsia recurvata, an epiphytic bromeliad. J Trop Ecol. 2010;26:571-81.

30. Tello SD. Estudio del perfil químico de dos especies relacionadas troficamente: Ipomoea murucoides Roem et Schult. (Convolvulaceae) y Ogdoecosta biannularis Boh. (Coleoptera: Chrysomeliadae). Bachelor Thesis México: UAEM; 2005.

31. Vergara-Torres CA, Pacheco-Álvarez MC, Flores-Palacios A. Host preference and host limitation of vascular epiphytes in a tropical dry forest of Central Mexico. J Trop Ecol. 2010;26:563-70

32. Rzedowski J. La vegetación de México. 1st ed. Limusa: México; 1978

33. Carranza E. Familia Convolvulaceae: Flora del Bajío y de regiones adyacentes, vol. 151; 2007. p. 1-131.

34. Martínez PG, Orozco-Segovia A, Martorell C. Efectividad de algunos tratamientos pre-germinativos para ocho especies leñosas de la mixteca alta oaxaqueña con características relevantes para la vegetación. Bol Soc Bot Méx. 2006;79:9-20.

35. Gibson DJ, Connolly, Hartnnet, Weidenhamer JD. Designs for greenhouse studies of interactions between plants. J Ecol. 1999;87:1-16.

36. Maiti R, Jana D, Das UK, Ghosh D. Antidiabetic effect of aqueous extract of seed of Tamarindus indica in streptozotocin-induced diabetic rats. J Ethnopharmacol. 2004;92:85-91.

37. Crawley MJ. GLIM for ecologist. Oxford: Boston. Blackwell Scientific; 1998.

38. Bates D, Mächler M, Bolker B, Walker S. Fitting linear mixed-effects models using Ime4. J Stat Softw. 2015;67:148. https://doi.org/10.18637/jss.v067.i01.

39. R Core Team. R: A language and environment for statistical computing. Vienna: R Foundation for Statistical Computing; 2017. https://www.R-project.org/

40. Hothorn T, Bretz F, Westfall P. Simultaneous inference in general parametric models. Biom J. 2008;50:346-63.

41. Laterra P, Bazzalo ME. Seed-to-seed allelopathic effects between two invaders of burned Pampa grasslands. Weed Res. 1999;39:297-308.

42. Shiting Z, Junpeng L, Xiaohui B. Seed-to-seed potential allelopathic effects between Ligularia virgaurea and native grass species of Tibetan alpine grasslands. Ecol Res. 2011;26:47-52.

43. IAS. First congress on allelopathy: a science for the future. Cadiz, Spain. 1996

44. Galindo JCG, Macias FA, García-Díaz MD, Jorrín J. Chemistry of host-parasite interactions. In: Macías FA, Galindo JCG, Molinillo JMG, Cutler HG, editors. Allelopathy. Chemistry and mode of action of allelochemicals. Boca Raton: CRC Press; 2004

45. Eich E. Solanaceae and convolvulaceae: secondary metabolites. Berlin: Springer; 2008.

46. Anaya AL, Sabourin DJ, Hernández-Bautista BE, Méndez I. Allelopathic potential of Ipomoea tricolor (Convolvulaceae) in a greenhouse experiment. J Chem Ecol. 1995;21:1085-102.

47. Sinkkonen A. Modelling the effect of autotoxicity on density-depend phytotoxicity. J Theor Biol. 2007;244:218-27.

48. Qasem RL. Parasitic Weeds and allelopathy: from the hypothesis to the proof. In: Reigosa MJ, Pedrol N, González L, editors. Allelopathy: a physiological process with ecological implications. Dordrecht: Springer; 2006.
49. Inderjit, Callaway RM. Experimental designs for the study of allelopathy. Plant Soil. 2003;256:1-11.

50. Baskin CC, Baskin JM. Seeds: ecology, biogeography, and evolution of dormancy and germination. 1st ed. USA: Academic; 1998.

51. Moles AT, Westoby M. What do seedlings die from and what are the implications for evolution of seed size. Oikos. 2004;106:93-199.

52. Mazzoleni S, Bonanomi G, Giannino F, Rietkerk M, Dekker SC. Is plant biodiversity driven by decomposition process? An emerging new theory on plant biodiversity. Comm Ecol. 2007:8:103-9.

53. Bonanomi G, Legg C, Mazzoleni S. Autoinhibition of germination and seedling establishment by lecheate of Calluna vulgaris leaves and litter. Commun Ecol. 2005;6:203-8.

54. Bonanomi G, Rietkerk M, Dekker SC, Mazzoleni S. Islands of fertility induce co-occurring negative and positive plant-soil feedbacks promoting coexistence. Plant Ecol. 2008;197:207-18.

55. Hanley ME, Fenner M, Edwards PJ. The effect of mollusc grazing on seedling recruitment in artificially created grassland gaps. Oecologia. 1996;106:240-6.

56. Romero-Nápoles J. Morfología y biología de Ogdoecosta biannularis (Coleóptera: Chrysomelidae) en su huésped silvestre Ipomoea murucoides (Convolvulaceae) en el Estado de Morelos, México. Folia Entomológica Mexicana. 1990:78:85-93.

\section{Publisher's Note}

Springer Nature remains neutral with regard to jurisdictional claims in published maps and institutional affiliations.
Ready to submit your research? Choose BMC and benefit from:

- fast, convenient online submission

- thorough peer review by experienced researchers in your field

- rapid publication on acceptance

- support for research data, including large and complex data types

- gold Open Access which fosters wider collaboration and increased citations

- maximum visibility for your research: over $100 \mathrm{M}$ website views per year

At BMC, research is always in progress.

Learn more biomedcentral.com/submissions 